\title{
Badania złączy spawanych bimetalu zgrzewanego wybuchowo stali niestopowej Grade 60 ze stopem Monel 400
}

\author{
Investigations of butt joints \\ of explosion welded bimetal plate \\ - non-alloy steel Grade 60 with Monel 400
}

\section{Streszczenie}

W pracy przedstawiono wyniki badań doczołowych złączy spawanych bimetalu stal niestopowa SA516 Grade 60 - monel 400 (SB127 UNS 04400). Badany bimetal został wytworzony przez zgrzewanie wybuchowe. Określono właściwości mechaniczne, rozkład twardości oraz strukturę otrzymanych złączy. Zwrócono uwagę na trudności technologiczne spawania tego rodzaju materiału oraz możliwość generowania niezgodności spawalniczych.

Słowa kluczowe: złącza różnorodne, zgrzewanie wybuchowe, technologia spawania

\begin{abstract}
The paper presents the research results of butt welded joints of bimetal plate type non-alloy steel SA516 Grade 60 - Monel 400 (SB127 UNS 04400). Bimetal plate was performed by the explosion welding. The mechanical properties, hardness distribution and microstructure of the joint were revealed. Difficulty of welding of this kind of material and the possibility to generate welding imperfections was highlighted.
\end{abstract}

Keywords: dissimilar joints, explosion welding, welding procedure

\section{Wstęp}

W konstrukcjach spawanych coraz częściej stosowane są materiały platerowane w celu uzyskania kombinacji żądanych właściwości - głównie odporności na korozję lub odporności na zużycie - przy niższych kosztach niż w przypadku zastosowania litego materiału.

Prowadzone w wielu krajach prace mają na celu uproszczenie metod wytwarzania bimetali, przy równoczesnym zachowaniu odpowiednich właściwości fizycznych, mechanicznych oraz eksploatacyjnych

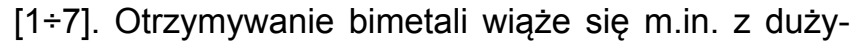
mi nakładami finansowymi, na które składają się złożone i kosztowne cykle technologiczne. Najczęściej stosowane metody wytwarzania płyt i blach platerowanych to metody odkształceniowe. Spośród nich należy wyróżnić wybuchowe metody łączenia, ze względu na uzyskanie charakterystycznego, falistego międzypowierzchniowego połączenia o bardzo dobrych właściwościach mechanicznych, a zwłaszcza dużej odporności na odrywanie.

Wybuchowe metody łączenia mają wiele zalet, do których można zaliczyć [8]:

- możliwość łączenia materiałów, których spajanie innymi metodami jest niemożliwe;

- możliwość zgrzewania elementów zarówno o bardzo dużych, jak i małych powierzchniach;

- bardzo dobre właściwości mechaniczne, technologiczne oraz eksploatacyjne połączeń.

Dr inż. Grzegorz Rogalski; mgr inż. Karolina Prokop; dr inż. Dariusz Fydrych; dr hab. inż. Jerzy Łabanowski, prof. nzw. PG - Politechnika Gdańska.

Autor korespondencyjny/Corresponding author: grogalski@mech.pg.gda.pl 
Platerowane półfabrykaty sa powszechnie stosowane w wielu gałęziach przemysłu m.in. w przemyśle energetycznym oraz stoczniowym. Wymienniki ciepła są typowymi urządzeniami, w których od lat stosuje się platerowane elementy zgrzewane wybuchowo na dna sitowe, dennice czy płaszcze. Takie urządzenia pracują z różnego rodzaju czynnikami roboczymi, często bardzo agresywnymi chemicznie [9]. $Z$ tego powodu wymagane jest stosowanie odpowiednich technologii przetwórstwa platerów (a zwłaszcza spawania), które nie wpłyną negatywnie na właściwości warstwy wierzchniej plateru oraz trwałość połączenia z płytą platerowaną. Na rysunku 1 przedstawiono wymiennik ciepła z wężownicą U-rurową, w którym głowicę wykonano z plateru zgrzewanego wybuchowo.

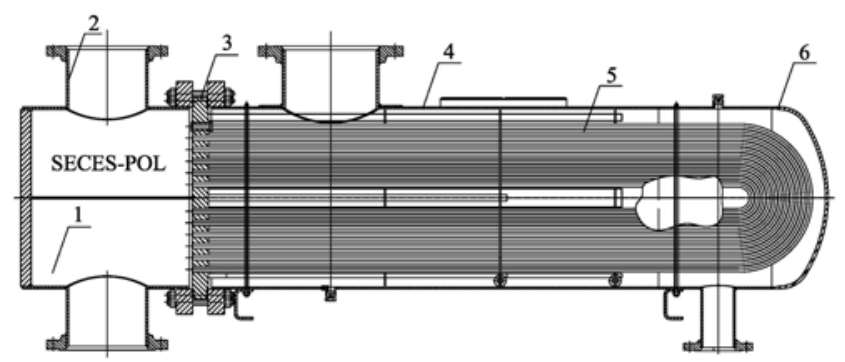

Rys. 1. Płaszczowy wymiennik ciepła z U-rurową wężownicą produkowany przez firmę SECESPOL Sp. z o.o.: 1 - głowica, 2 - króciec, 3 - płyta sitowa, 4 - płaszcz zbiornika, 5 - wężownica U-rurowa, 6 - dennica [10]

Fig. 1. Heat exchanger with U-tube coil manufactured by SECESPOL Sp. z o.o.: 1 - channel head; 2 - outlet connector; 3 - tube sheet, 4 - shell, 5 - U-tube coil, 6 - bottom

\section{Badania własne}

Celem badań było określenie struktury i właściwości mechanicznych doczołowych złączy spawanych wykonanych z bimetalu zgrzewanego wybuchowo stal niestopowa SA516 Grade 60 z monelem 400 (SA127 UNS 04400) oraz weryfikacja poprawności zastosowanej technologii spawania. Blacha platerowana została wykorzystana przez firmę SECESPOL Sp. z o.o w konstrukcji głowicy wymiennika ciepła, w którym jednym z czynników roboczych jest solanka.

Plan badań obejmował:

1. Opracowanie technologii spawania.

2. Wykonanie spawanych złączy próbnych z bimetalu.

3. Przeprowadzenie badań nieniszczących:

a) Badania wizualne (VT),

b) Badania penetracyjne (PT).
4. Przeprowadzenie badań niszczących:

a) Próba zginania bocznego,

b) Pomiary twardości HV10,

c) Badania metalograficzne makroskopowe i mikroskopowe.

Dla badań nieniszczących założono, że wykonane złącza muszą odpowiadać poziomowi jakości B zgodnie z PN-EN ISO 5817 [11], natomiast dla badań niszczących jako kryterium akceptacji przyjęto wymagania normy PN-EN ISO 15614-1 [12].

\section{Opracowanie wytycznych technologii spawania i wykonanie złączy próbnych}

Złącza próbne wykonano z blachy bimetalowej zgrzewanej wybuchowo o grubości $26 \mathrm{~mm}$. Płyta podstawowa ze stali SA516 Grade 60 miała grubość $20 \mathrm{~mm}$, natomiast grubość warstwy monelu 400 wynosiła $6 \mathrm{~mm}$. Plater został wytworzony przez firmę EXPLOMET S.J. Stal Grade 60 to stal niestopowa, przeznaczona do budowy urządzeń ciśnieniowych. Jej europejskim odpowiednikiem jest stal P265GH wg PN-EN 10028:2005. Stal ta charakteryzuję się dobrą spawalnością i nie stwarza wielu problemów podczas wykonywania złączy. Monel 400 to stop niklu z miedzią o dużej odporności na oddziaływanie korozyjne różnego rodzaju agresywnych mediów, m.in.: wody morskiej, pary wodnej o wysokiej temperaturze, kwasu solnego, wodnych roztworów zasad i soli. Uwzględniając wiele innych zalet, materiał ten znalazł zastosowanie do budowy wymienników ciepła, płuczek solankowych, podgrzewaczy wody morskiej, instalacji do uszlachetniania i separacji izotopów uranu

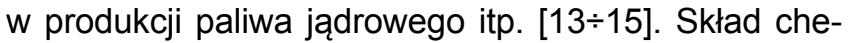
miczny obu gatunków materiałów zastosowanych do wytworzenia bimetalu przedstawiono w tablicach I i II.

Do wykonania złączy próbnych zastosowano dwie metody spawania:

- od strony stali niestopowej (SA516 Grade 60) wykonano je metodą 136 (FCAW),

- od strony monelu 400 złącza wykonano metodą 131 (MIG prądem pulsującym).

Spoina od strony stali niestopowej wykonana została przy użyciu drutu rdzeniowego rutylowego wg PN-EN ISO 17632-A: T 462 P M 2 H5. Natomiast spoinę od strony monelu 400 wykonano z zastosowaniem drutu litego o oznaczeniu wg EN-ISO 18274: SNi4060 (NiCu30Mn3Ti). Dla obu rodzajów spoiwa zastosowano druty o średnicy 1,2 mm. Przy spawaniu FCAW użyto gazu osłonowego M21 (82\% Ar $\left.+18 \% \mathrm{CO}_{2}\right)$, natomiast dla metody 131 gazu

Tablica I. Skład chemiczny stali ASME SA516 Grade 60, \% masy

Table I. Chemical composition of ASME SA516 Grade 60 steel, wt. \%

\begin{tabular}{|c|c|c|c|c|c|c|c|c|}
\hline Stal & $\mathrm{C}_{\max }$ & $\mathrm{Si}_{\max }$ & $\mathrm{Mn}$ & $\mathrm{P}_{\max }$ & $\mathrm{S}_{\max }$ & $\mathrm{Ni}_{\max }$ & $\mathrm{Ti}_{\max }$ & $\mathrm{V}_{\max }$ \\
\hline Grade $60(1.0425)$ & 0,18 & 0,40 & $0,95 \div 1,50$ & 0,015 & 0,008 & 0,3 & 0,03 & 0,02 \\
\hline
\end{tabular}

Tablica II. Skład chemiczny monelu 400, \% masy

Table II. Chemical composition of Monel 400, wt.\%

\begin{tabular}{|c|c|c|c|c|c|c|c|}
\hline Gatunek & $\mathrm{C}_{\max }$ & $\mathrm{Mn}_{\max }$ & $\mathrm{S}_{\max }$ & $\mathrm{Si}_{\max }$ & $\mathrm{Ni}_{\min }$ & $\mathrm{Cu}$ & $\mathrm{Fe}_{\max }$ \\
\hline Monel 400 & 0,3 & 2,0 & 0,024 & 0,5 & 63,0 & $28 \div 34$ & 2,5 \\
\hline
\end{tabular}


I3 $(70 \% \mathrm{Ar}+30 \% \mathrm{He}) \cdot$ W tablicy III przedstawiono schemat przygotowania elementów do spawania, kolejność wykonania ściegów oraz przykładowe parametry spawania.

Na podstawie parametrów spawania przedstawionych w tablicy III wykonano złącza próbne (rys. 2). W pierwszej kolejności wykonano cztery warstwy od strony stali niestopowej, następnie rozpoczęto spawanie od strony monelu. Zaobserwowano podczas wtapiania się stopiwem NiCu30Mn3Ti w stal niestopową intensywne dymienie oraz pokrywanie się lica ściegu warstwą tlenków. W związku z tym zastosowano czyszczenie poszczególnych warstw. Po wykonaniu drugiej warstwy obserwowane wcześniej zjawiska nie miały już miejsca. Spawanie złącza zakończono, układając pozostałe ściegi wypełniające od strony stali Grade 60 . Wykonane w ten sposób złącza poddano badaniom zgodnie z planem badań.

\section{Badania nieniszczące}

Badania wizualne wykonano zgodnie z wymaganiami PN-EN ISO 17637 [16]. Nie stwierdzono niezgodności spawalniczych zarówno od strony stali niestopowej, jak i od strony monelu, a na rysunku 2 nie widać pęknięć
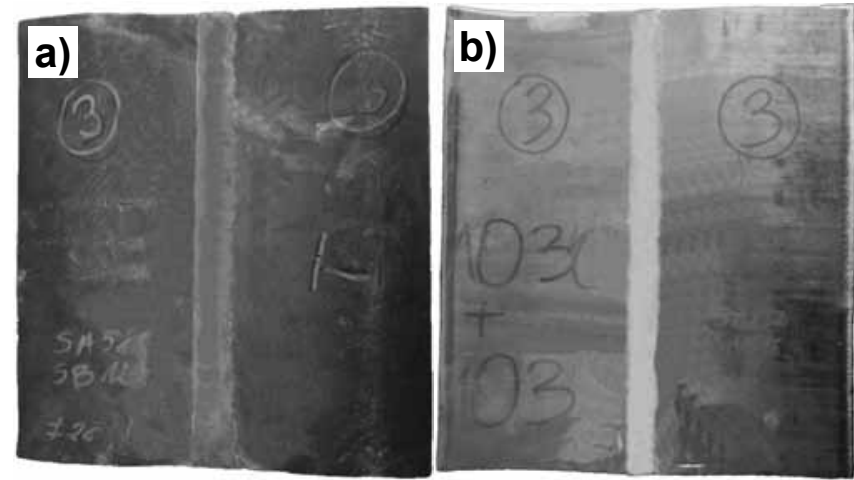

Rys. 2. Wykonane złącze, widok: a) od strony stali niestopowej Grade 60 , b) od strony monelu 400

Fig. 2. Joint view: a) from the Grade 60 steel side, b) from the Monel 400 side

Tablica III. Skład chemiczny stali ASME SA516 Grade 60, \% masy Table III. Chemical composition of ASME SA516 Grade 60 steel, wt. \%

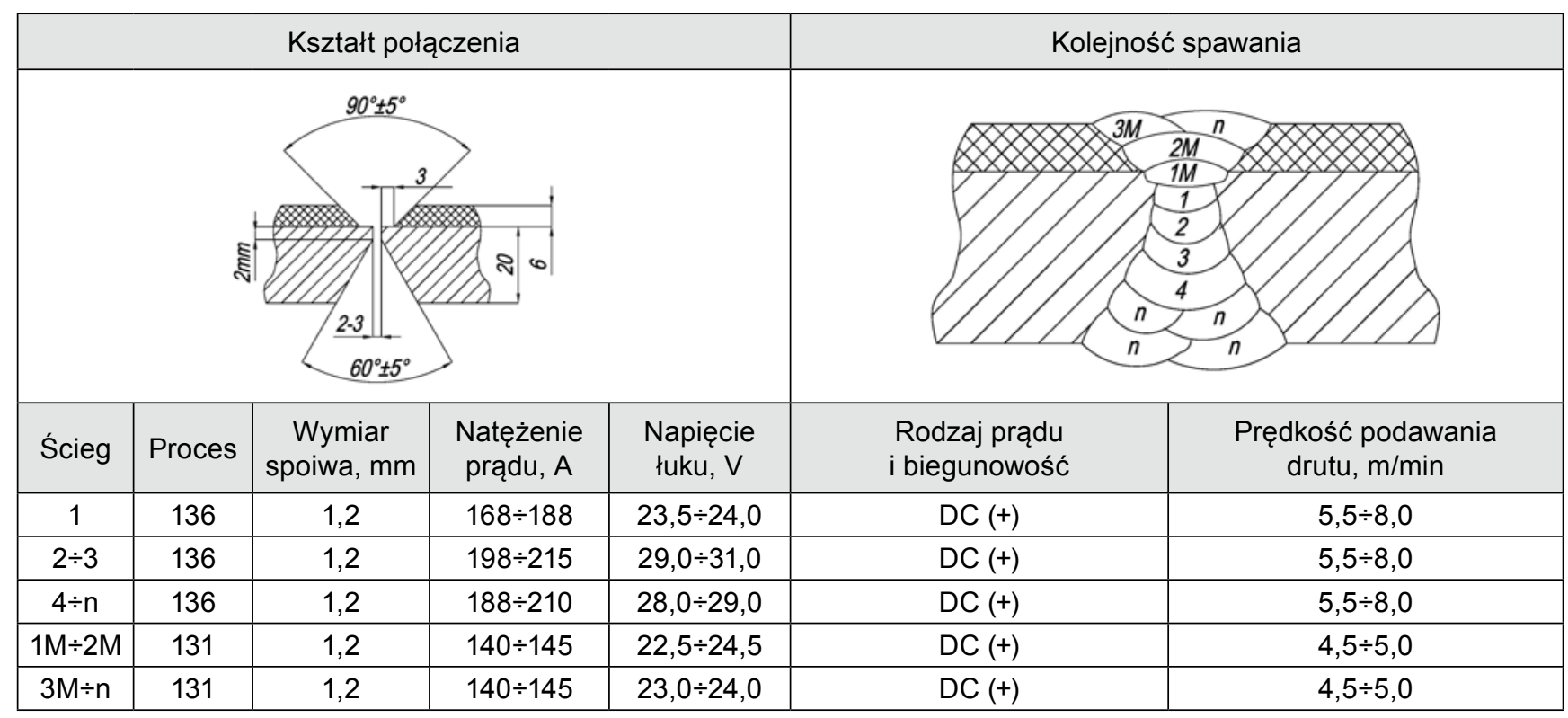

powierzchniowych, podtopień, odpowiednia jest też geometria spoiny.

Badania penetracyjne przeprowadzono zgodnie z PN-EN ISO 3452-1 [17] zarówno od strony stali niestopowej, jak i monelu. Badania PT potwierdziły wyniki badań wizualnych. Nie stwierdzono niezgodności na obu powierzchniach.

\section{Badania niszczące \\ Próba zginania bocznego}

Próbę zginania bocznego wykonano zgodnie z wytycznymi PN-EN ISO 5173 [18]. Sposób przygotowania próbek pokazano na rysunku 3. Jako kryterium akceptacji próby przyjęto brak pęknięć lub naderwań o maksymalnej długości wszystkich nieciągłości równych $3 \mathrm{~mm}$ przy kącie gięcia do $180^{\circ}$. Założono przeprowadzenie sześciu prób zginania bocznego (TSBB) dla próbek pobranych poprzecznie z jednego złącza spawanego. Próbki wycinano mechanicznie. Powierzchnie boczne frezowano na wymiar $10 \mathrm{~mm}$. Oś spoiny znajdowała się w części środkowej próbki. Zastosowano trzpień gnący o średnicy $D=4 T$, gdzie $T$ - grubość próbki. Na rysunku 4 przedstawiono reprezentatywną próbkę po badaniu.

Zginanie boczne próbek spawanych nie spowodowało powstania pęknięć lub naderwań w obrębie złącza spawanego. Wynik próby zginania oceniono jako

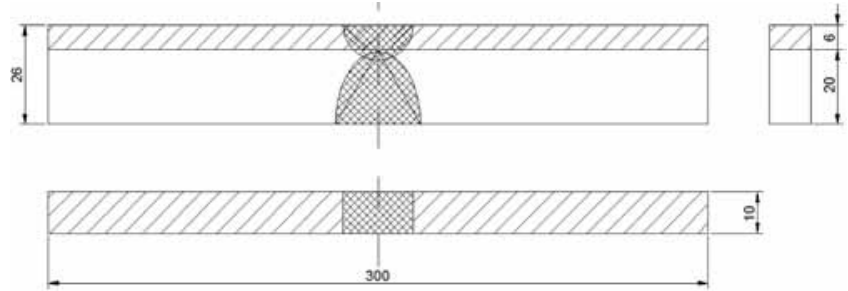

Rys. 3. Próbka do próby zginania bocznego

Fig. 3. Specimen for side bend test pozytywny. Natomiast na powierzchniach bocznych 
zginanych próbek obserwowano niewielkie rozwarstwienia na granicy zgrzanych metali. Powierzchnie boczne zginanych próbek przedstawiono na rysunku 5.

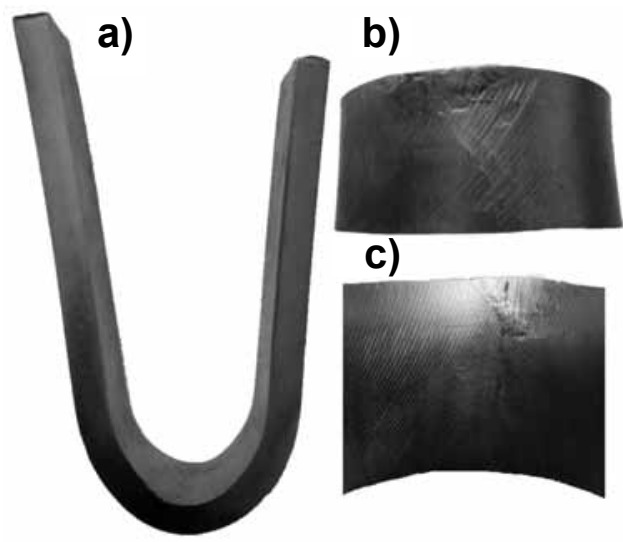

Rys. 4. Próbka nr 1 po próbie zginania bocznego, widok: a) zgiętej próbki, b) powierzchni rozciąganej, c) powierzchni ściskanej

Fig. 4. Specimen No. 1 after side bend test, view of: a) the bent specimen, b) expanded surface, c) compression surface

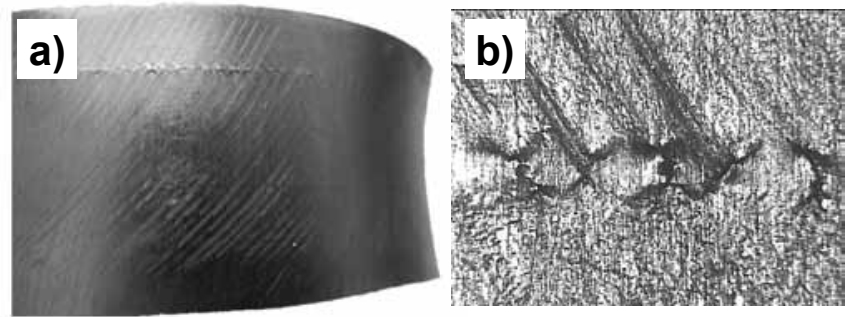

Rys. 5. Rozwarstwienia na bocznej powierzchni próbki, widok: a) makroskopowy, próbka $\mathrm{nr} 4$, b) rozwarstwienia na granicy zgrzanych metali, pow. $25 \times$

Fig. 5. Delamination on the side surface of the specimen, view: a) the macroscopic, specimen no. 4, b) delamination at the border line between explosion welded metals, magn $25 \times$

Obserwowane rozwarstwienia sa prawdopodobnie wynikiem obecności wydzieleń faz międzymetalicznych w obszarze połączenia zgrzewanego plateru. Wydzielenia twardych i kruchych faz międzymetalicznych (głównie fazy sigma) mogą powstać w obrębie złącza zgrzewnego wybuchowo na skutek szybko przebiegających przemian strukturalnych podczas oddziaływania fali detonacyjnej. Platerowanie wybuchem przebiegające w ułamkach sekundy powoduje, że powstające warstewki faz międzymetalicznych mają zwykle bardzo małą grubość i występują tylko na ograniczonym obszarze jako wtrącenia.

\section{Pomiary twardości złączy}

Pomiar twardości złączy bimetalu prowadzono metodą Vickersa zgodnie z wytycznymi PN-EN ISO 6507-1 [19]. Badania wykonano przy użyciu twardościomierza VEB. Obciążenie wgłębnika wynosiło 98,07 N (HV10). Badania wykonano w trzech liniach pomiarowych, jak pokazano na rysunku 6 :

- $2 \mathrm{~mm}$ od lica spoiny od strony monelu 400,

- $2 \mathrm{~mm}$ od grani spoiny w monelu, przy linii zgrzania,

- $2 \mathrm{~mm}$ od lica spoiny od strony stali Grade 60.

Wyniki pomiarów przedstawiono na rysunku 7.

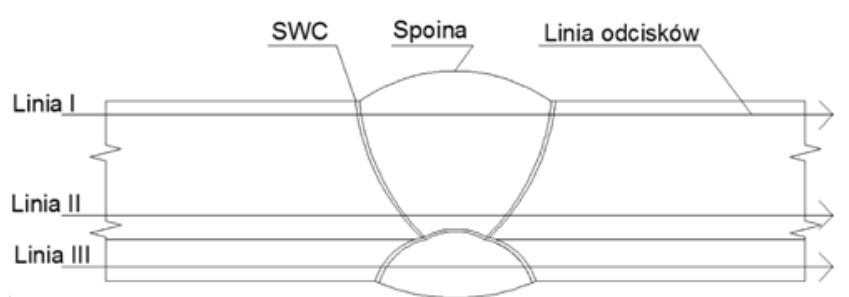

Rys. 6. Przekrój złącza spawanego z naniesionymi liniami pomiaru twardości

Fig. 6. Hardness measurement lines on the cross-section of the weIded joint

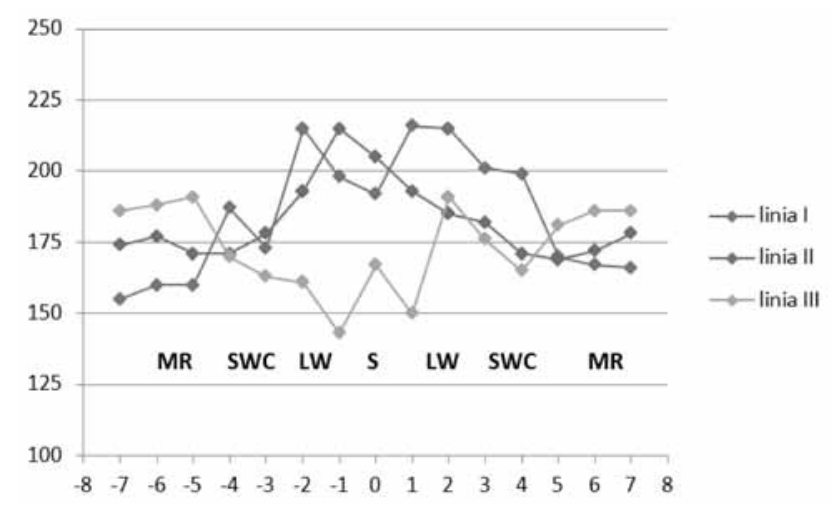

Rys. 7. Wykres zbiorczy rozkładów twardości złącza spawanego bimetalu; MR - materiał rodzimy, SWC - strefa wpływu ciepła, LW - linia wtopienia, S - spoina

Fig. 7. Hardness distribution across bimetal welded joint; MR - base material, SWC - heat affected zone, LW - fusion line, S - weld

Rozkład twardości na przekroju złącza wzdłuż linii pomiarowych I i II ma charakterystyczny przebieg dla stali niskowęglowych niestopowych. Twardość stali SA516 Grade 60 nie przekracza wartości 180 HV10, natomiast w spoinie obserwowano zwiększoną twardość do około 210 HV10. Krytyczny obszar złącza - strefa wpływu ciepła nie wykazywała nadmiernego utwardzenia. Odnotowano maksymalne twardości tego obszaru w granicach 215 HV10, a w związku z tym można wnioskować, że nie występują tam struktury hartownicze. Pomiary twardości wzdłuż linii III w obszarze monelu 400 wykazały niższą twardość spoiny (do 170 HV10), twardość

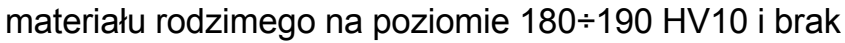
utwardzenia w SWC. Jest to skutkiem zastosowania wysokoniklowego materiału dodatkowego do spawania.

Próby twardości wykonane w sąsiedztwie linii zgrzania stali SA516 Grade 60 i monelu 400 wykazały nieznaczny wzrost twardości w materiale rodzimym stali Grade 60 (180 HV10) oraz większe utwardzenie monelu (ok. 215 HV10). Ten wzrost twardości związany jest z utwardzeniem materiałów w wyniku zgniotu podczas odkształcenia wywołanego falą detonacyjną. Wyniki pomiarów twardości świadczą o poprawnie dobranych parametrach spawania, jak i geometrii rowka spawalniczego, co w tym przypadku ma szczególnie istotne znaczenie.

\section{Badania metalograficzne makroskopowe}

Badania metalograficzne wykonano zgodnie z PNEN ISO 17639 [20]. Próbki przygotowano zgodnie ze standardową procedurą (wycięcie na pile ramowej, 
szlifowanie, trawienie). Makrostrukturę złącza przedstawiono na rysunkach 8 i 9. Powierzchnię stali Grade 60 trawiono 4\% roztworem kwasu azotowego. Do trawienia powierzchni monelu 400 wykorzystano odczynnik Marble'a $\left(\mathrm{HCl}+\mathrm{HNO}_{3}+\mathrm{H}_{2} \mathrm{O}\right)$. Obserwacje makrostruktury nie wykazały obecności niezgodności spawalniczych. Uzyskano symetryczne spoiny o poprawnym przetopieniu krawędzi (rys. 11). Dobrze widoczne są różnice pomiędzy obszarami złącza spawanego oraz charakterystyczne faliste złącze pomiędzy zgrzanymi materiałami.

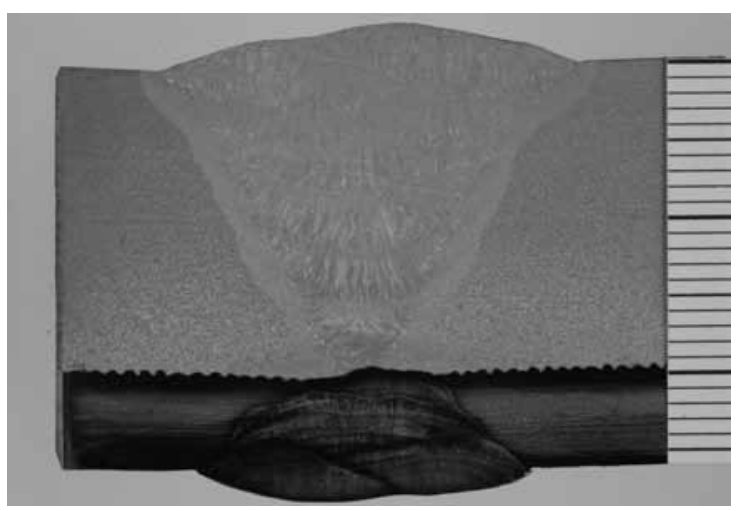

Rys. 8. Makroskopowy obraz przekroju złącza spawanego. Pow. 5x Fig. 8. Macroscopic image of the cross section of the welded joint. Magn. 5x

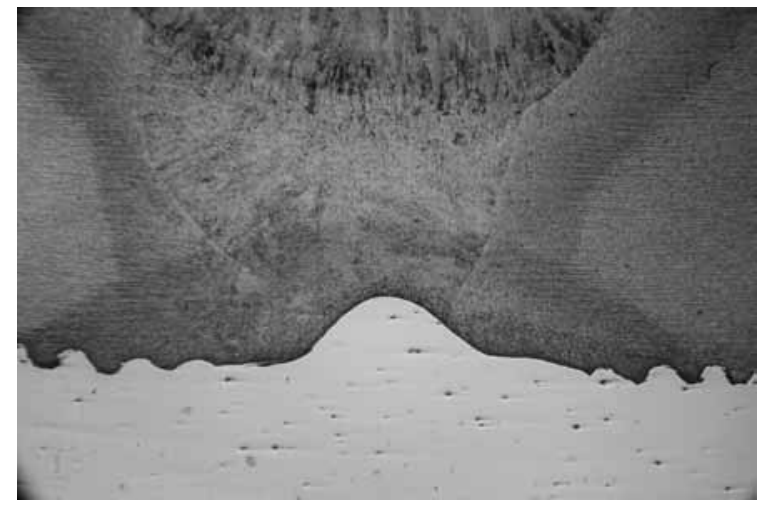

Rys. 9. Przekrój złącza spawanego w obszarze zgrzeiny. Pow. 10x Fig. 9. Cross section of the bimetal plate welded joint. Magn. 10x

\section{Badania metalograficzne mikroskopowe}

Badania mikroskopowe wykonano zgodnie z PN-EN ISO 17639 [20]. Wykorzystano próbki stosowane w badaniach metalograficznych makroskopowych. Próbki ponownie wyszlifowano zgrubnie oraz dokładnie. Następnie wytrawiono je $4 \%$ nitalem, ujawniając mikrostrukturę od strony stali Grade 60. Po wykonaniu serii mikrofotografi, próbkę wytrawiono roztworem kwasów azotowego i octowego, co pozwoliło na obserwację mikrostruktury monelu 400.

Obrazy mikrostruktury stali niestopowej w różnych obszarach złącza, tj. w MR, SWC oraz w spoinie przedstawiono na rysunkach $10 \div 12$. Stal Grade 60 wykazuje drobnoziarnistą strukturę ferrytyczno-perlityczną o układzie pasmowym (rys. 10). Spoina ma charakterystyczną dendrytyczną strukturę ferrytyczno-perlityczną (rys. 11). W SWC złącza obserwowano rozrośnięte ziarna ferrytu oraz quasi-perlitu. Nie stwierdzono obecności iglastych struktur hartowania (rys. 12). Mikrostruktura złącza w obrębie stali świadczy o poprawnie dobranym materiale dodatkowym do spawania oraz parametrach spawania.

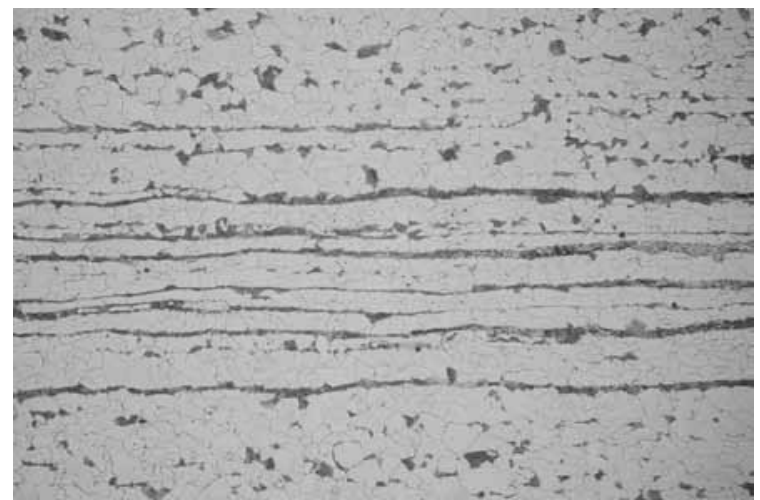

Rys. 10. Mikrostruktura materiału rodzimego stali SA516 Grade 60. Traw. Nital. Pow. 200x

Fig. 10. Microstructure of base material of steel SA516 Grade 60. Nital etch. Magn. 200x

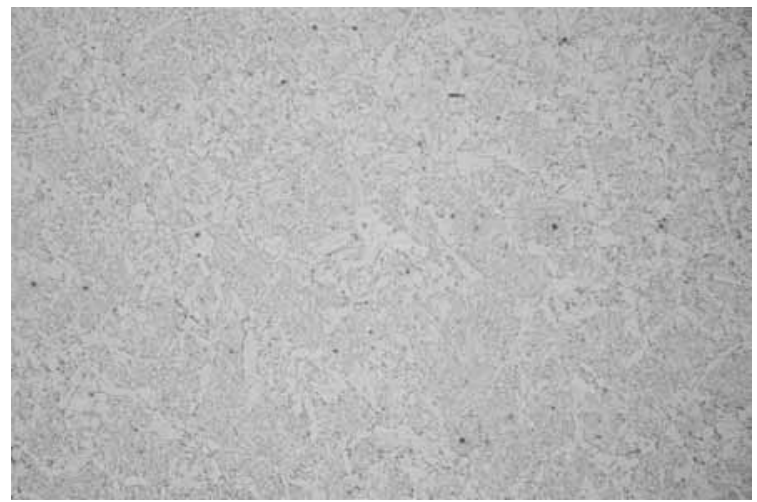

Rys. 11. Mikrostruktura spoiny w złączu stali SA516 Grade 60. Traw. Nital. Pow. 200x

Fig. 11. Weld metal microstructure of SA516 Grade 60 steel. Nital etch. Magn. 200x

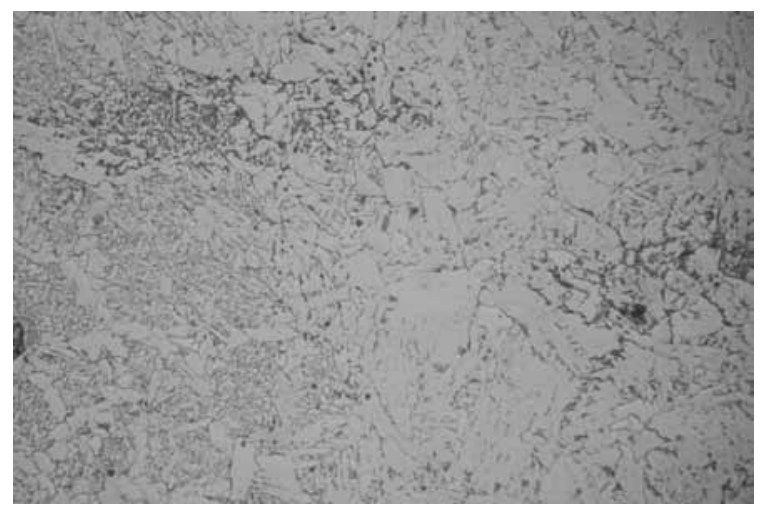

Rys. 12. Mikrostruktura SWC złącza stali SA516 Grade 60. Traw. Nital. Pow. 400x

Fig. 12. HAZ microstructure of SA516 Grade 60 steel. Nital etch. Mag. $400 \times$

Połączenie zgrzewane wybuchowo pomiędzy stalą Grade 60 a monelem 400 (rys. 13 i 14) wykazuje charakterystyczną budowę falistą. Taka budowa jest poprawna i zapewnia optymalne właściwości wytrzymałościowe oraz eksploatacyjne. W strukturze stali widać zróżnicowaną wielkość ziaren wynikającą z następujących po sobie procesów zgniotu i rekrystalizacji. $\mathrm{Na}$ granicy połączenia z monelem struktura stali uległa znacznemu rozdrobnieniu. 
Na rysunku 14 przedstawiono budowę połączenia zgrzewanego od strony monelu. Widoczna jest struktura austenityczna monelu oraz warstwa pośrednia na granicy zgrzewanych materiałów. Duże prędkości zgrzewania powoduje powstawanie w złączach obszarów warstwy pośredniej, która jest wynikiem stopienia i krzepnięcia warstwy metalu podczas procesu zgrzewania. W praktyce dąży się do uzyskania połączeń falistych bez warstwy pośredniej lub z niewielkim jej udziałem. W składzie warstwy pośredniej mogą występować fazy międzymetaliczne, wykazuje ona też dużą

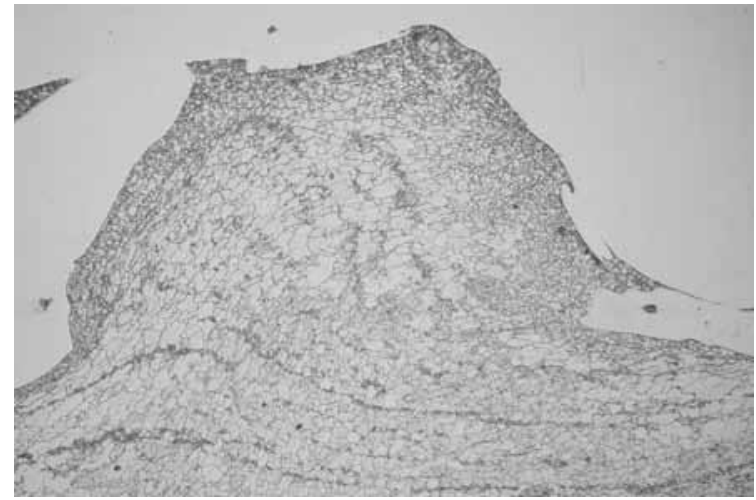

Rys. 13. Połączenie zgrzewane stali SA516 Grade $60 \mathrm{z}$ monelem 400. Traw. Nital. Pow. 200x

Fig. 13. The boundary zone of explosion welded joint between SA516 Grade 60 steel and Monel 400. Nital etch. Magn. 200×

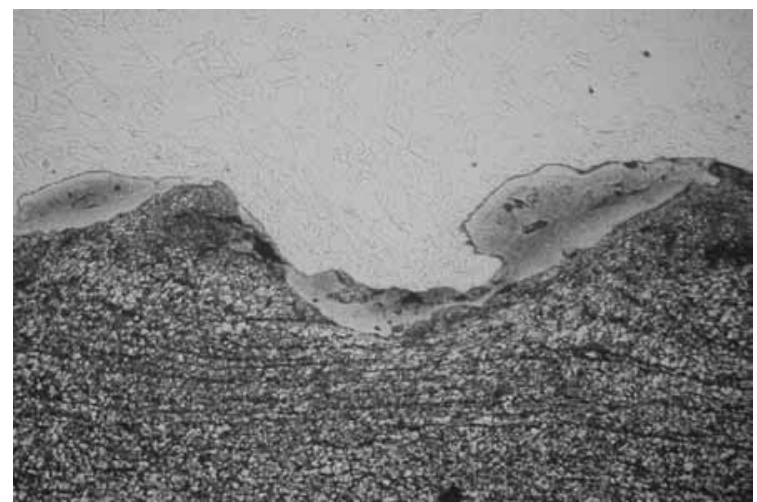

Rys. 14. Połączenie zgrzewane stali SA516 z monelem 400 . Widoczna struktura austenityczna monelu $z$ warstwą pośrednią oraz licznymi jamami usadowymi. Pow. 100x

Fig. 14. The boundary zone of explosion welded joint between SA516 Grade 60 steel and Monel 400. Visible austenitic structure of Monel with the intermediate layer and numerous shrinkage cavities. Magn. 100x

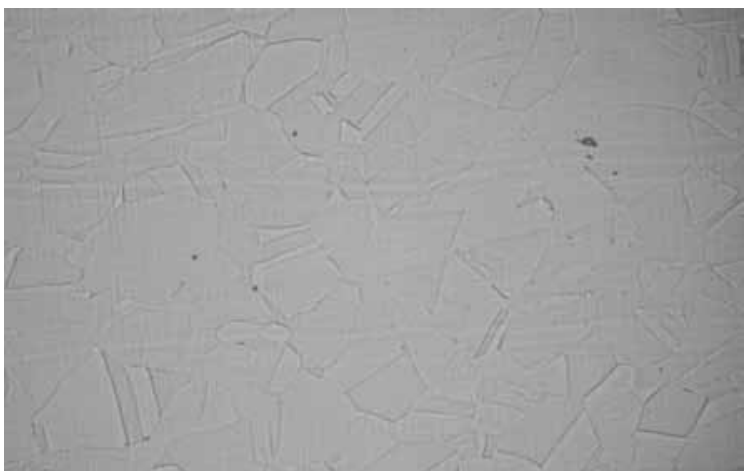

Rys. 15. Austenityczna struktura monelu 400. Pow. $400 \times$

Fig. 15. Austenitic structure of Monel 400. Magn. 400x twardość oraz liczne defekty w postaci jam usadowych, pęknięć i pęcherzy.

Obrazy mikrostruktury monelu 400 w różnych obszarach złącza, MR, SWC oraz w spoinie przedstawiono na rysunkach $15 \div 18$. Spoina wykonana w monelu (rys. 16) posiada strukturę austenityczną o charakterystycznej budowie kolumnowej z wyraźnie zaznaczonymi granicami ziaren. W SWC złącza ziarna austenitu uległy widocznemu rozrostowi. Obszar wtopienia pomiędzy stalą Grade 60 a monelem 400 wykazuje skokową zmianę struktury bez utworzenia stref przejściowych (rys. 18).

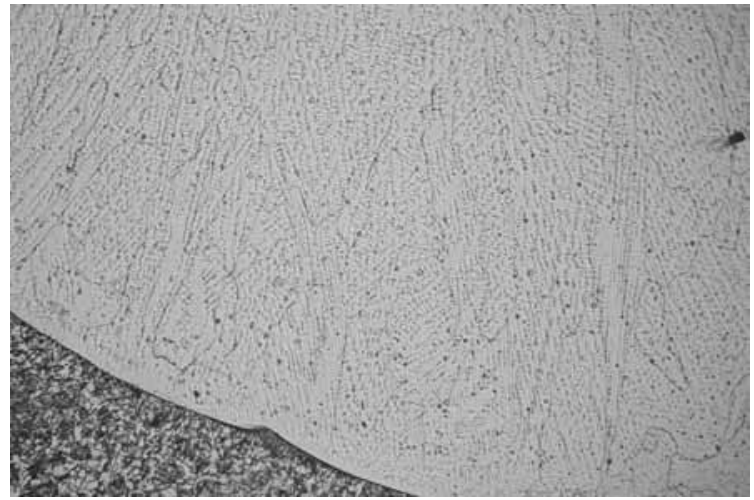

Rys. 16. Dendrytyczna struktura spoiny wykonanej w monelu 400. Pow. 200x

Fig. 16. Dendritic structure of the weld in Monel 400. Magn. 200×

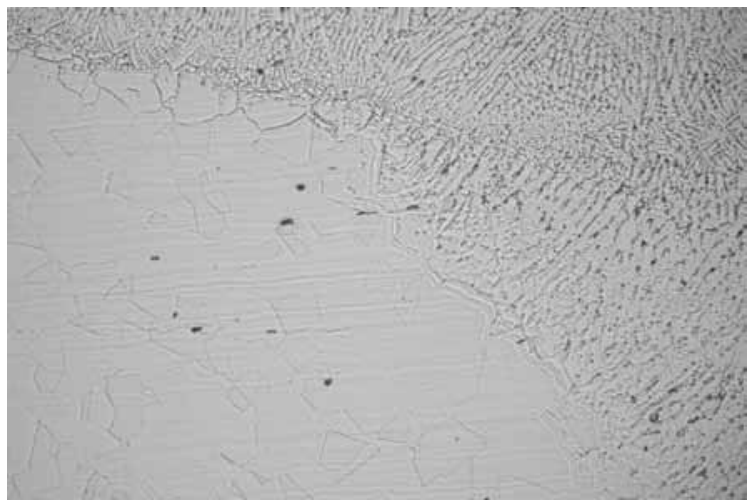

Rys. 17. Struktura SWC w złączu monelu 400. Pow. 200x Fig. 17. Microstructure of HAZ in Monel 400. Magn. 200x

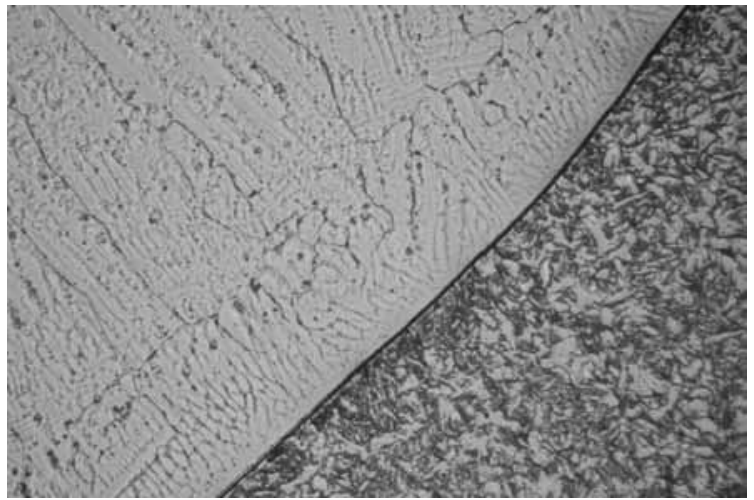

Rys. 18. Linia wtopienia w złączu stal niestopowa SA516 Grade 60 - monel 400. Pow. 400x

Fig. 18. Fusion line between SA516 Grade 60 steel and Monel 400 . Magn. 400x 


\section{Podsumowanie}

Przeprowadzone badania oraz analiza ich wyników pozwalają na stwierdzenie, że opracowana technologia spawania złączy doczołowych stali SA516 Grade 60 platerowanej stopem monelu 400 (SA127 UNS 04400) została poprawnie zaprojektowana. Zastosowano odpowiednie przygotowanie krawędzi elementów do spawania oraz pozostałe zmienne istotne mające wpływ na przebieg procesu spawania. Badania wizualne (VT), penetracyjne (PT) oraz makroskopowe nie ujawniły niezgodności spawalniczych. Próby zginania bocznego (TSBB) przy kącie zginania $180^{\circ}$ nie wywołały pęknięć i naderwań na rozciąganych płaszczyznach i oceniono je jako pozytywne. Badania mikroskopowe złączy ujawniły występowanie struktur typowych dla materiałów podstawowych (struktura ferrytyczno-perlityczna stali, struktura austenityczna monelu). Zmiany strukturalne w obszarze SWC oraz w linii wtopienia dla poszczególnych obszarów złącza są niewielkie i nie wpływają na właściwości wytrzymałościowe oraz eksploatacyjne.
Nie stwierdzono znacznego wzrostu twardości w obszarze SWC złącza, zarówno od strony monelu 400 , jak i od strony stali Grade 60 . Maksymalna wartość twardości w SWC dla stali to 216 HV10, a monelu $191 \mathrm{HV} 10$. W obszarze charakterystycznym dla zgrzewania wybuchowego maksymalną twardość 215 HV10 stwierdzono w monelu 400, co świadczy o większej podatności tego stopu na utwardzenie w wyniku zgniotu w stosunku do stali Grade 60 . Stosunkowo niewielkie zmiany twardości w tym obszarze i pozytywne wyniki prób zginania plateru świadczą o poprawnie wykonanym procesie zgrzewania wybuchowego.

Otrzymane wyniki dają podstawę do stwierdzenia, że poprawnie dobrano materiał dodatkowy do spawania. W przypadku słabej zwilżalności podczas spawania drutem SNi4060 (stopiwo dla monelu) uzyskanie takiego wyniku byłoby niemożliwe. W takim przypadku należałoby wykonać warstwę buforową (1M - tabl. III) stopiwem wysokoniklowym (min. 93\% Ni), a następnie zastosować spoiwo do spawania monelu.

\section{Literatura}

[1] Palmer T. A., Elmer J. W., Brasher D., Butler D., Riddle R.: Development of an explosive welding process for producing high-strength welds between niobium and 6061-t651 aluminum. Thin interlayers of $\mathrm{Nb}$ and $\mathrm{Al}$ were used to improve the joining of thicker plates. Welding Journal 85 (11), 2006, s. $252-263$.

[2] Grignon F., Benson D., Vecchio K. S., Meyers M. A.: Explosive welding of aluminum to aluminum: analysis, computations and experiments. International Journal of Impact Engineering 30 (10), 2004, s. 1333-1351.

[3] Paul H., Lityńska-Dobrzyńska L., Miszczyk M., Prażmowski M.: Microstructure and Phase Transformations Near the Bonding Zone of Al/Cu Clad Manufactured by Explosive Welding. Archives of Metallurgy and Materials 57 (4), 2012, s. $1151-1162$

[4] Wronka B.: Testing of explosive welding and welded joints. The microstructure of explosive welded joint and their mechanical properties. Wavy character of the process and joint quality. International Journal of Impact Engineering 38 (5), 2011, s. 309-313.

[5] Sun X., Tao J., Guo X.: Bonding properties of interface in Fe/Al clad tube prepared by explosive welding. Transactions of Nonferrous Metals Society of China 21 (10), 2011, s. $2175-2180$

[6] Rogalski G., Fydrych D., Walczak W.: Zastosowanie zgrzewania wybuchowego do wytwarzania kompozytów metalowych z osnową aluminiową. Przegląd Spawalnictwa 6/2013.

[7] Fydrych D., Rogalski G., Walczak W.: Wpływ cyklu cieplnego na właściwości zgrzewanych wybuchowo złączy stal-aluminium. Przegląd Spawalnictwa 6/2013.
[8] Walczak W.: Zgrzewanie wybuchowe metali i jego zastosowanie. WNT Warszawa 1989.

[9] Świerczyńska A., Rogalski G., Fydrych D.: Badania właściwości i struktury spawanych austenitycznych rur wymienników ciepła. Przegląd Spawalnictwa 6/2010.

[10] www.secespol.pl

[11] PN-EN ISO 5817: Spawanie. Złącza spawane ze stali, niklu, tytanu i ich stopów (z wyjątkiem spawanych wiązką). Poziomy jakości według niezgodności spawalniczych.

[12] PN-EN ISO 15614-1: Specyfikacja i kwalifikowanie technologii spawania metali. Badanie technologii spawania. Część 1: Spawanie łukowe i gazowe stali oraz spawanie łukowe niklu i stopów niklu.

[13] Davis J.R. (red.): ASM Specialty Handbook: Nickel, cobalt and their alloys. ASM International, USA 2000.

[14] DuPont J. N., Lippold J. C., Kiser S. D.: Welding metallurgy and weldability of nickel- base alloys. New Jersey, Wiley 2009.

[15] Nickel alloys. Henry Wiggin \& Company Limited, Publications No. 3367D, 1972.

[16] PN-EN ISO 17637: Badania nieniszczące złączy spawanych. Badania wizualne złączy spawanych.

[17] PN-EN ISO 3452-1: Badania nieniszczące. Badania penetracyjne. Zasady ogólne.

[18] PN-EN ISO 5173:. Badania niszczące spoin w materiałach metalowych. Badanie na zginanie.

[19] PN-EN ISO 6507-1:. Metale. Pomiar twardości sposobem Vickersa. Część 1: Metoda badań.

[20] PN-EN ISO 17639: Badania niszczące spawanych złączy metali. Badania makroskopowe i mikroskopowe złączy spawanych. 